\title{
NON-STANDARD WORD WRITING IN POS KOTA NEWS TITLE
}

\author{
Dicky Septiawan \\ Universitas Indraprasta PGRI \\ Nur Irwansyah \\ Universitas Indraprasta PGRI \\ Siti Jubei \\ Universitas Indraprasta PGRI \\ Jl. Raya Tengah No. 80, Kel. Gedong, Kec. Pasar Rebo, Jakarta Timur 13760; Indonesia \\ e-mail: Agungricky14@gmail.com
}

\begin{abstract}
The habit of reading the newspaper by itself will be able to familiarize readers more familiar with the language of the newspaper. However, in fact in terms of the users of the language in the newspaper classified as inadequate. The public seemed never ceased to demand the newspaper to use the language normative and standard in the presentation of news. The purpose of this study is to know the writing of non-standard words in the title of the Pos Kota newspaper. Furthermore, it is expected to that many readers would know about non-standard words. The research method used to analyze the writing of non-standard words in the Pos Kota newspaper title is a descriptive method. From a total of 25 words divided, Basic, Affix and Combined Words get the same amount of 5 words. Beheading Words gets 3 words. Re-form, Prepositions s, Abbreviations and Acronyms Words get 2 words. Numbers get 1 word. Meanwhile, Particles,, Pronouns, and Article Words get 0 words. There are still a lot of non-standard vocabulary written in newspapers that can cause readers to be more familiar with non-standard vocabulary than standard vocabulary later. In the end, it will cause many errors in the use of standard vocabulary by readers.
\end{abstract}

Key Words: word writing, non-standard words, Pos Kota newspaper.

\begin{abstract}
Article History: Received: 10/09/2020; Revised: 26/10/2020; Accepted: 14/11/2020; Published: 31/12/2020
How to Cite (MLA 7th): Septiawan, Dicky, Nur Irwansyah, and Siti Jubei. "Non-Standard Word writing in Pos Kota news title." Hortatori Jurnal Pendidikan Bahasa dan Sastra Indonesia 4.2 (2020): 99-108. Print/Online. Copyrights Holder: Dicky Septiawan, Nur Irwansyah, dan Siti Jubei. First Publication: Hortatori Jurnal Pendidikan Bahasa dan Sastra Indonesia (2020).
\end{abstract}

\section{Pendahuluan}

Media massa memiliki kontribusi yang luar biasa bagi kemajuan suatu bangsa. Dunia modern yang ditandai oleh perkembangan teknologi informasi dan komunikasi yang semakin maju, berdampak signifikan terhadap tata kehidupan manusia di berbagai aspek. Tidak dapat dihindari, arus ini menyeret setiap orang ke dunia digital, dengan terminilogi yang sering disebut dengan virtual. Salah satu bentuk dunia digital terelaborasi dalam komunikasi melalui media massa. Bagian terpenting dari perkembangan media massa ini adalah jaringan internet, yang sudah masuk hingga ke pelosok daerah. Salah satu kontribusi yang dimainkan media massa surat kabar yang terbit harian adalah menanamkan kebiasaan pembaca kepada masyarakat. Apabila semakin banyak masyarakat terbiasa membaca akan menjadi tradisi dan membudaya, sehingga terjadilah budaya membaca di kalangan masyarakat ( Abdulkarim et al., 2014).

Pada era masyarakat informasi industri media massa mau tidak mau harus bertransformasi dari bentuk analog menjadi digital. Karena ciri khas produk teknologi di era ini menawarkan produktivitas, 
efisiensi, kecepatan dan lintas batas. Perangkat komunikasi teks, audio dan visual yang sebelumnya terpisah kini berpadu dan konvergen dalam satu perangkat transmisi yang menggabungkan fungsi media penyiaran lama ke dalam satu platform media baru (Respati, 2014).

Media mempunyai posisi strategis dalam mendukung demokratisasi kehidupan berbangsa dan bernegara. Namun untuk membangun karakter media yang transparan dalam pemberitaaan, penyiaran independen dan bebas dari kepentingan politik maupun bisnis, bukan pekerjaan yang mudah (Susanto, 2017). Penulisan yang ada di surat kabar sering menggunakan ragam bahasa yang baku. Ragam baku disebut juga ragam ilmiah. Ragam ini merupakan ragam bahasa orang berpendidikan yakni bahasa dunia pendidikan. Ragam ini jugalah yang kaidah-kaidahnya paling lengkap jika dibandingkan dengan ragam bahasa yang lain. Namun, masih banyak orang yang menyamakan pengertian bahasa baku dengan bahasa yang baik dan benar. Bahasa yang dipergunakan di dalam situasi tidak resmipun dianggap sebagai bahasa baku. Makna baku tampaknya tidak dipahami secara benar hal ini disebabkan oleh keengganan orang mencari makna istilah baku dan bahasa baku itu di dalam kamus Umum atau Kamus Istilah Linguistik, baik dari bahasa Indonesia maupun dari bahasa Asing, terutama dalam bahasa Inggris (Jamilah, 2017). Kata baku adalah kata-kata yang digunakan dalam situasi formal atau resmi yang penulisannya sesuai dengan kaidah-kaidah yang dibakukan. Untuk mengetahui baku atau tidaknya sebuah kata dapat dilihat dari segi lafal, ejaan, gramatika, dan kenasionalan-nya (Setiawati, 2016).

Koran atau surat kabar adalah suatu penerbitan yang ringan dan mudah dibuang, biasanya dicetak pada kertas berbiaya rendah yang disebut kertas koran, yang berisi berita-berita terkini dalam berbagai topik. Topiknya bisa berupa peristiwa politik, kriminalitas, olahraga, tajuk rencana, prdiksi cuaca. Surat kabar juga biasa berisi kartun, tekateki silang (TTS) dan hiburan lainnya. Ada juga surat kabar yang dikembangkan untuk bidang-bidang tertentu, misalnya berita untuk industri tertentu, penggemar olah raga tertentu, penggemar seni atau partisipan kegiatan tertentu. Jenis surat kabar umum biasanya diterbitkan setiap hari, kecuali pada hari-hari libur (Taufik, 2012). Pengertian tentang berita sudah dijelaskan oleh banyak ahli yaitu, laporan yang diperoleh seseorang mengenai suatu peristiwa yang telah terjadi pada akhirnya akan dipublikasikan di media massa (Amalia, 2016). Berita juga merupakan kumpulan informasi yang berupa teks, ucapan maupun gambar yang dibutuhkan oleh manusia untuk menambah informasi yang dimiliki (Rahardja et al., 2018). Surat kabar Pos Kota berdiri ditengah maraknya surat kabar, dengan harapan misi dapat membuat sesuatu hal yang positif bagi rakyat kecil dalam melakukan pembelaan bila tidak mendapatkan perlakuan hukum yang adil (Rizky, 2012).

Seiring dengan perkembangan era globalisasi, media massa mempunyai peran yang sangat strategis dalam suatu negara, termasuk di Indonesia. Teknologi Informasi dan komunikasi telah mengarahkan masyarakat untuk selalu membutuhkan informasi tentang segala hal di dalam kehidupannya. Masyarakat dengan tingkat ekonomi di level bawah, tidak akan dengan leluasa mengakses informasi sesuai dengan kebutuhannya, karena keterbatasan sarana dan biaya untuk mengakses informasi tersebut. Kesenjangan dalam mengakses informasi diantara kelas ekonomi atas dengan kelas ekonomi bawah sangat kentara kita lihat. Walaupun media massa bersifat massa dan bisa dikonsumsi ataupun diakses oleh siapapun, namun pada kenyataannya tidak semua masyarakat dapat mengaksesnya. Terutama masyarakat miskin yang dalam kehidupan sehari-hari kekurangan untuk memenuhi kebutuhan pokok sehari-harinya (Rosana, 2013).

Penulisan kata tidak baku dalam sebuah media memang masih banyak terjadi dan menjadi kebiasaan yang sudah berjalan sampai sekarang. Penelitian yang relevan pertama tentang penulisan kata tidak baku sudah dilakukan oleh Dewi pada tahun 2014. Judul penelitannya yaitu, Gaya Bahasa Berita Media Online Di Indonesia: Judul Menarik Tidak Harus Tidak Baku. Penelitian ini meninjau tata bahasa pemberitaan di media online di Indonesia dengan analisis studi kasus dengan mempelajari judul berita yang ada di dua portal berita utama di Indonesia, yaitu detik.com dan kompas.com pada hari yang sama, dan menilik perbedaan penulisan judul-judul berita tersebut (Dewi, 2014).

Penelitian yang relevan kedua, yaitu berjudul Kata Baku Pada Karya Ilmiah Mahasiswa Program Studi Pendidikan Bahasa Dan Sastra Indonesia Universitas Muhammadiyah Purworejo. Dalam penelitian ini ada dua kaidah yang dijadikan rujukan, yakni kaidah morfologis dan kaidah leksikon. Penerapan kaidah morfologis dan leksikon dalam karya ilmiah mahasiswa Program Studi Pendidikan Bahasa dan Sastra Indonesia Universitas Muhammadiyah Purworejo dikategorikan baik karena kata-kata yang digunakan umumnya sesuai dengan kaidah, baik kaidah morfologis maupun kaidah leksikon. Sangat sedikit kata yang menyimpang kedua kaidah tersebut dan hanya ada beberapa kata yang digunakan secara 
tidak konsisten. Ketidakkonsistenan penerapan kaidah morfologis terdapat, terutama, pada kaidah afiksasi (Fakhrudin, et. al., 2019).

Penelitian yang kami lakukan ini mengkaji dan menganalisis tentang penulisan kata tidak baku pada judul berita surat kabar Pos Kota. Penelitian ini merupakan penelitian terbaru yang dilakukan berkaitan dengan penulisan kata tidak baku pada judul berita surat kabar Pos Kota edisi terbit selama Februari sampai dengan Maret 2020.

\section{Metode}

Penelitian ini menggunakan metode kualitatif deskriptif yang menitikberatkan pada analisis isi. Metode penelitian deskriptif adalah yang berkenaan dengan pertanyaan terhadap keberadaan variabel mandiri, baik hanya pada satu variabel atau lebih (variabel yang berdiri sendiri) (Nuryastini et. al, 2018).

Penelitian ini dilakukan dengan cara mengumpulkan informasi, mengumpulkan data, dengan menggunakan teknik studi kepustakaan, dan mencari-cari buku-buku yang berhubungan dengan penggunaan kata tidak baku. Teknik penelitian yang digunakan peneliti dalam penelitian ini adalah menggunakan teknik dokumentasi dan tabel yang berisikan penulisan kata tidak baku dalam surat kabar Pos Kota. Data yang sudah didapatkan dari surat kabar Pos Kota akan dikelompokkan sesuai penulisan kata yang terdapat pada PUEBI.

Sehubungan dengan tujuan khusus penelitian, sumber data dalam penelitian ini adalah judul surat kabar Pos Kota. Fokus penelitian ini adalah penulisan kata pada ejaan bahasa Indonesia, sedangkan subfokusnya adalah kata dasar, kata berimbuhan, bentuk ulang, gabungan kata, pemenggalan kata, kata depan, partikel, singkatan dan akronim, angka dan bilangan, kata ganti, dan kata sandang.

\section{Hasil dan Diskusi}

Data penelitian yang diambil adalah penulisan kata tidak baku pada judul surat kabar Pos Kota. Penulisan kata merupakan salah satu ejaan yang ada pada Pedoman Umum Ejaan Bahasa Indonesia (PUEBI). PUEBI sendiri adalah ejaan bahasa Indonesia yang berlaku sejak tahun 2015. Ejaan ini menggantikan ejaan sebelumnya, yaitu Ejaan Yang Disempurnakan (EYD) edisi revisi tahun 1987. Selain itu, ejaan adalah segala bentuk aturan terkait penulisan tata bahasa dalam bahasa Indonesia (Anto et. al., 2017).

Tabel 1 Penulisan Kata Tidak Baku Pada Judul Surat Kabar

\begin{tabular}{|c|c|c|c|}
\hline No. & Judul Berita & Edisi & Kata Tidak Baku \\
\hline 1. & $\begin{array}{l}\text { Kata Dasar } \\
\text { Priska-Alexandra Luar Biasa Rebut Juara di Level Yunior } \\
\text { Australia Terbuka }\end{array}$ & Sabtu, 1 Februari 2020 & Yunior \\
\hline 2. & Bawa Narkoba, Mobil Ambulan Tabrak Petugas & Minggu, 2 Februari 2020 & Ambulan \\
\hline 3. & $\begin{array}{l}\text { Terkait Bisnis Properti Syari'ah Bodong. Polda Jatim akan } \\
\text { Panggil Ust. Yusuf Mansur }\end{array}$ & Senin, 3 Februari 2020 & Syari'ah \\
\hline 4. & $\begin{array}{l}\text { Kembang Desa Jadi Jaminan Utang. Dijual Mucikari ke Pria } \\
\text { Hidung Belang. Orang Tua Dijerat Pinjaman Uang. }\end{array}$ & Selasa, 11 Februari 2020 & Mucikari \\
\hline 5. & Telor Impor Ilegal Asal India Dimusnahkan & Kamis, 13 Februari 2020 & Telor \\
\hline 1. & $\begin{array}{l}\text { Kata Berimbuhan } \\
\text { Sepulang Salat Berjamaah Diam-Diam Menemui WIL }\end{array}$ & Rabu, 5 Februari 2020 & Berjamaah \\
\hline 2. & $\begin{array}{l}\text { Kaum Milineal Rentan Alami Obesitas. Bisa Mempengaruhi } \\
\text { Kesehatan }\end{array}$ & Rabu, 5 Februari 2020 & Mempengaruhi \\
\hline
\end{tabular}


3. Layanan Perekaman E-KTP Dibuka di HBKB. Berolah Raga Senin, 10 Februari 2020 Sambil Urus Identitas Kependudukan

4. Trio Band
Nyerah

5. Parkir di Bahu Jalan 64 Kendaraan Dikempesi.

\section{Bentuk Ulang}

1. Pemilik Shabu Diamankan

2. Enam Panti Pijat Ditutup. Diduga Beri Layanan Esek-Esek.

\section{Gabungan Kata}

1. Budidaya Sayur Mayur dan Buah-Buahan. Laboratorium Pertanian Dibangun di Kramatjati

2. Warga RW 08 Kapuk Muara Kini Punya Gedung Serba Guna. Jadi Ruang Interaksi Sosial.

3. Artis Nanie Darham Bandar Kokain. Salah Satu Pelanggan Pengacara Senior

4. Pembangunan Saluran Terkendala Fasos-Fasum. Komplek Perumahan Kartini Tergenang

5. Kawasan Segi Tiga Emas Marak Parkir Liar. 264 Motor Dicabut Pentil

Pemenggalan Kata
1. Uang Mesjid Rp20 Juta Dibawa Kabur Marbot

2. Sepetak Tanah Yahudi Buat Mesjid

3. Mendekati Puasa Ramadhan. Polsek Cikande Gelar Razia Miras dan PSK

\section{Kata Depan}

1. Jakarta 'Kelelep' Lagi Nih! Hujan Deras, Air Laut Pasang, Kali Meluap. Warga Ngungsi di Kontener.

2. Lempar Kursi di Konggres PAN Apa Amien Rais Ikut Terlempar?

\section{Singkatan dan Akronim}

1. Ketua MPR: Masyarakat Menghendaki PPHN. Amandemen UUD 1945

2. Melerai Remaja Tawuran Kaki Bripda Agus Disabet Sajam

\section{Angka dan Bilangan}

1. Minimarket Diacak-acak Maling. Gasak Belasan Slop Rokok dan CD
Senin, 10 Februari 2020

Kamis, 13 Februari 2020

Nyerah

Dikempesi

Shabu

Esek-Esek

Budidaya

Serba Guna

Bandar Kokain

Komplek Perumahan

Segi Tiga

Marbot

Jumat, 7 Februari 2020

Jumat, 28 Februari 2020

Mesjid

Ramadhan

Di Kontener

Di Konggres

Rabu, 12 Februari 2020

Amandemen UUD 1945

Minggu, 1 Maret 2020

Bripda Agus Disabet

Belasan Slop

Penulisan Kata terbagi menjadi 11 antara lain Kata Dasar, Kata Berimbuhan, Bentuk Ulang, Gabungan Kata, Pemenggalan Kata, Kata Depan, Partikel, Singkatan dan Akronim, Angka dan Bilangan, Kata Ganti, dan Kata Sandang.

1. Kata Dasar

a. Surat kabar edisi tanggal 1 Februari 2020

1) Judul berita

"Priska-Alexandra Luar Biasa Rebut Juara di Level Yunior Australia Terbuka"

2) Analisis

Kata Yunior dalam kalimat tersebut termasuk Kata Dasar dan merupakan kata tidak baku karena kata yunior seharusnya menjadi kata Junior dan merupakan satu kesatuan yang disebut dengan kata dasar dalam PUEBI. Jadi, Penulisan yang tepat dalam judul surat kabar tersebut menjadi "Priska-Alexandra Luar Biasa Rebut Juara di Level Junior Australia Terbuka" 
b. Surat kabar edisi tanggal 2 Februari 2020

1) Judul berita

"Bawa Narkoba, Mobil Ambulan Tabrak Petugas"

2) Analisis

Kata Ambulan dalam kalimat tersebut termasuk Kata Dasar dan merupakan kata tidak baku karena kata Ambulan seharusnya menjadi kata Ambulans dan merupakan satu kesatuan yang disebut dengan kata dasar dalam PUEBI. Jadi, Penulisan yang tepat dalam judul surat kabar tersebut menjadi "Bawa Narkoba, Mobil Ambulans Tabrak Petugas"

c. Surat kabar edisi tanggal 3 Februari 2020

1) Judul berita

"Terkait Bisnis Properti Syari’ah Bodong. Polda Jatim akan Panggil Ust. Yusuf Mansur"

2) Analisis

Kata Syari'ah dalam kalimat tersebut termasuk Kata Dasar dan merupakan kata tidak baku karena kata Syari'ah seharusnya menjadi kata Syariat dan merupakan satu kesatuan yang disebut dengan kata dasar dalam PUEBI. Jadi, Penulisan yang tepat dalam judul surat kabar tersebut menjadi "Terkait Bisnis Properti Syariat Bodong. Polda Jatim akan Panggil Ust. Yusuf Mansur"

d. Surat kabar edisi tanggal 11 Februari 2020

1) Judul berita

"Kembang Desa Jadi Jaminan Utang. Dijual Mucikari ke Pria Hidung Belang. Orang Tua Dijerat Pinjaman Uang"

2) Analisis

Kata Mucikari dalam kalimat tersebut termasuk Kata Dasar dan merupakan kata tidak baku karena kata Mucikari seharusnya menjadi kata Muncikari dan merupakan satu kesatuan yang disebut dengan kata dasar dalam PUEBI. Jadi, Penulisan yang tepat dalam judul surat kabar tersebut menjadi "Kembang Desa Jadi Jaminan Utang. Dijual Mucikari ke Pria Hidung Belang. Orang Tua Dijerat Pinjaman Uang"

e. Surat kabar edisi tanggal 13 Februari 2020

1) Judul berita

"Telor Impor Ilegal Asal India Dimusnahkan"

2) Analisis

Kata Telor dalam kalimat tersebut termasuk Kata Dasar dan merupakan kata tidak baku karena kata Telor seharusnya menjadi kata Telur dan merupakan satu kesatuan yang disebut dengan kata dasar dalam PUEBI. Jadi, Penulisan yang tepat dalam judul surat kabar tersebut menjadi "Telur Impor Ilegal Asal India Dimusnahkan"

2. Kata Berimbuhan

a. Surat kabar edisi tanggal 5 Februari 2020

1) Judul berita

"Sepulang Salat Berjamaah Diam-Diam Menemui WIL"

2) Analisis

Kata Berjamaah dalam kalimat tersebut termasuk Kata Berimbuhan dan merupakan kata tidak baku karena kata Berjamaah seharusnya menjadi kata Berjemaah dan menggunakan imbuhan Ber- yang ditulis serangkai dengan kata dasarnya yaitu Jemaah yang disebut dengan kata berimbuhan dalam PUEBI. Jadi, Penulisan yang tepat dalam judul surat kabar tersebut menjadi "Sepulang Salat Berjemaah Diam-Diam Menemui WIL"

b. Surat kabar edisi tanggal 5 Februari 2020

1) Judul berita

"Kaum Milineal Rentan Alami Obesitas. Bisa Mempengaruhi Kesehatan"

2) Analisis

Kata Mempengaruhi dalam kalimat tersebut termasuk Kata Berimbuhan dan merupakan kata tidak baku karena kata Mempengaruhi seharusnya menjadi kata Memengaruhi dan menggunakan imbuhan awalan $M e$ - akhiran - I yang ditulis serangkai dengan kata dasarnya yaitu Pengaruh yang disebut dengan kata berimbuhan dalam PUEBI. Jadi, Penulisan yang tepat dalam judul surat kabar tersebut menjadi "Kaum Milineal Rentan Alami Obesitas. Bisa Memengaruhi Kesehatan" 
c. Surat kabar edisi tanggal 10 Februari 2020

1) Judul berita

"Layanan Perekaman E-KTP Dibuka di HBKB. Berolah Raga Sambil Urus Identitas Kependudukan"

2) Analisis

Kata Berolah Raga dalam kalimat tersebut termasuk Kata Berimbuhan dan merupakan kata tidak baku karena kata Berolah Raga seharusnya menjadi kata Berolahraga dan menggunakan imbuhan Ber- yang ditulis serangkai dengan kata dasarnya yaitu Olahraga yang disebut dengan kata berimbuhan dalam PUEBI. Jadi, Penulisan yang tepat dalam judul surat kabar tersebut menjadi "Layanan Perekaman E-KTP Dibuka di HBKB. BerolahRaga Sambil Urus Identitas Kependudukan"

d. Surat kabar edisi tanggal 10 Februari 2020

1) "Trio Bandit Curanmor Lintas Provinsi Dua Tersungkur Dibedil,1 Nyerah"

2) Analisis

Kata Nyerah dalam kalimat tersebut termasuk Kata Berimbuhan dan merupakan kata tidak baku karena kata Nyerah seharusnya menjadi kata Menyerah dan menggunakan imbuhan $M e$ - yang ditulis serangkai dengan kata dasarnya yaitu Serah yang disebut dengan kata berimbuhan dalam PUEBI. Jadi, Penulisan yang tepat dalam judul surat kabar tersebut menjadi "Trio Bandit Curanmor Lintas Provinsi Dua Tersungkur Dibedil,1 Menyerah"

e. Surat kabar edisi tanggal 13 Februari 2020

1) Judul berita

"Parkir di Bahu Jalan 64 Kendaraan Dikempesi"

2) Analisis

Kata Dikempesi dalam kalimat tersebut termasuk Kata Berimbuhan dan merupakan kata tidak baku karena kata Dikempesi seharusnya menjadi kata Mengempis dan menggunakan imbuhan $M e$ - yang ditulis serangkai dengan kata dasarnya yaitu Kempis yang disebut dengan kata berimbuhan dalam PUEBI. Jadi, Penulisan yang tepat dalam judul surat kabar tersebut menjadi "Parkir di Bahu Jalan 64 Kendaraan Mengempis"

3. Bentuk Ulang

a. Surat kabar edisi tanggal 1 Februari 2020

1) Judul berita "2 Pemilik Shabu Diamankan"

2) Analisis

Kata Shabu dalam kalimat tersebut termasuk Bentuk Ulang dan merupakan kata tidak baku karena kata Shabu seharusnya menjadi kata Sabu-Sabu karena ditulis dengan menggunakan tanda hubung (-) di antara unsur-unsurnya yang disebut dengan Bentuk Ulang dalam PUEBI. Jadi, Penulisan yang tepat dalam judul surat kabar tersebut menjadi "2 Pemilik Sabu-Sabu Diamankan"

b. Surat kabar edisi tanggal 5 Februari 2020

1) Judul berita

"Enam Panti Pijat Ditutup. Diduga Beri Layanan Esek-Esek"

2) Analisis

Kata Esek-Esek dalam kalimat tersebut termasuk Bentuk Ulang dan merupakan kata tidak baku karena kata Esek-Esek seharusnya menjadi kata Prostitusi karena ditulis dengan menggunakan tanda hubung (-) di antara unsur-unsurnya yang disebut dengan Bentuk Ulang dalam PUEBI. Jadi, Penulisan yang tepat dalam judul surat kabar tersebut menjadi "Enam Panti Pijat Ditutup. Diduga Beri Layanan Prostitusi”

4. Gabungan Kata

a. Surat kabar edisi tanggal 4 Februari 2020

1) Judul berita

"Budidaya Sayur Mayur dan Buah-Buahan. Laboratorium Pertanian Dibangun di Kramatjati"

2) Analisis

Kata Budidaya dalam kalimat tersebut termasuk Gabungan Kata dan merupakan kata tidak baku karena kata Budidaya seharusnya menjadi kata Budi Daya karena merupakan unsur gabungan kata yang lazim disebut dengan kata majemuk termasuk istilah khusus dan ditulis terpisah yang 
disebut dengan Gabungan Kata dalam PUEBI. Jadi, Penulisan yang tepat dalam judul surat kabar tersebut menjadi "Budi Daya Sayur-Mayur dan Buah-Buahan. Laboratorium Pertanian Dibangun di Kramatjati"

b. Surat kabar edisi tanggal 10 Februari 2020

1) Judul berita

"Warga RW 08 Kapuk Muara Kini Punya Gedung Serba Guna. Jadi Ruang Interaksi Sosial"

2) Analisis

Kata Serba Guna dalam kalimat tersebut termasuk Gabungan Kata dan merupakan kata tidak baku karena kata Serba Guna seharusnya menjadi kata Serbaguna karena merupakan gabungan kata yang sudah padu ditulis serangkai yang disebut dengan Gabungan Kata dalam PUEBI. Jadi, Penulisan yang tepat dalam judul surat kabar tersebut menjadi "Warga RW 08 Kapuk Muara Kini Punya Gedung Serbaguna. Jadi Ruang Interaksi Sosial”

c. Surat kabar edisi tanggal 11 Februari 2020

1) Judul berita

"Artis Nanie Darham Bandar Kokain. Salah Satu Pelanggan Pengacara Senior"

2) Analisis

Kata Bandar Kokain dalam kalimat tersebut termasuk Gabungan Kata dan merupakan kata tidak baku karena kata Bandar Kokain seharusnya menjadi kata Bandar Kokaina karena merupakan unsur gabungan kata yang lazim disebut dengan kata majemuk termasuk istilah khusus dan ditulis terpisah yang disebut dengan Gabungan Kata dalam PUEBI. Jadi, Penulisan yang tepat dalam judul surat kabar tersebut menjadi "Artis Nanie Darham Bandar Kokaina. Salah Satu Pelanggan Pengacara Senior"

d. Surat kabar edisi tanggal 12 Februari 2020

1) Judul berita

"Pembangunan Saluran Terkendala Fasos-Fasum. Komplek Perumahan Kartini Tergenang"

2) Analisis:

Kata Komplek Perumahan dalam kalimat tersebut termasuk Gabungan Kata dan merupakan

kata tidak baku karena kata Komplek Perumahan seharusnya menjadi kata Kompleks Perumahan karena merupakan unsur gabungan kata yang lazim disebut dengan kata majemuk termasuk istilah khusus dan ditulis terpisah yang disebut dengan Gabungan Kata dalam PUEBI. Jadi, Penulisan yang tepat dalam judul surat kabar tersebut menjadi "Pembangunan Saluran Terkendala Fasos-Fasum. Komplek Perumahan Kartini Tergenang"

e. Surat kabar edisi tanggal 13 Februari 2020

1) Judul berita

"Kawasan Segi Tiga Emas Marak Parkir Liar. 264 Motor Dicabut Pentil"

2) Analisis

Kata Segi Tiga dalam kalimat tersebut termasuk Gabungan Kata dan merupakan kata tidak baku karena kata Segi Tiga seharusnya menjadi kata Segitiga karena merupakan gabungan kata yang sudah padu ditulis serangkai yang disebut dengan Gabungan Kata dalam PUEBI. Jadi, Penulisan yang tepat dalam judul surat kabar tersebut menjadi "Kawasan Segi Tiga Emas Marak Parkir Liar. 264 Motor Dicabut Pentil”

5. Pemenggalan Kata

a. Surat kabar edisi tanggal 7 Februari 2020

1) Judul berita

"Uang Mesjid Rp20 Juta Dibawa Kabur Marbot” Edisi: Jumat,

2) Analisis

Kata Marbot dalam kalimat tersebut termasuk Pemenggalan Kata dan merupakan kata tidak baku karena kata Marbot seharusnya menjadi kata Marbut karena di tengah kata dasar terdapat dua huruf konsonan yang berurutan yaitu huruf $r$ dan huruf $b$ yang pemenggalannya di antara kedua huruf konsonan tersebut yang disebut dengan Pemenggalan Kata dalam PUEBI. Jadi, Penulisan yang tepat dalam judul surat kabar tersebut menjadi "Uang Mesjid Rp20 Juta Dibawa Kabur Marbut"

b. Surat kabar edisi tanggal 28 Februari 2020

1) Judul berita

"Sepetak Tanah Yahudi Buat Mesjid". 
2) Analisis

Kata Mesjid dalam kalimat tersebut termasuk Pemenggalan Kata dan merupakan kata tidak baku karena kata Mesjid seharusnya menjadi kata Masjid karena di tengah kata dasar terdapat dua huruf konsonan yang berurutan yaitu huruf $s$ dan huruf $j$ yang pemenggalannya di antara kedua huruf konsonan tersebut yang disebut dengan Pemenggalan Kata dalam PUEBI. Jadi, Penulisan yang tepat dalam judul surat kabar tersebut menjadi "Sepetak Tanah Yahudi Buat Masjid".

c. Surat kabar edisi tanggal 1 Maret 2020

1) Judul berita

"Mendekati Puasa Ramadhan. Polsek Cikande Gelar Razia Miras dan PSK"

2) Analisis

Kata Ramadhan dalam kalimat tersebut termasuk Pemenggalan Kata dan merupakan kata tidak baku karena kata Ramadhan seharusnya menjadi kata Ramadan karena di tengah kata dasar terdapat huruf konsonan di antara dua huruf vocal yaitu huruf $m$ yang pemenggalannya dilakukan sebelum huruf konsonan itu yang disebut dengan Pemenggalan Kata dalam PUEBI. Jadi, Penulisan yang tepat dalam judul surat kabar tersebut menjadi "Mendekati Puasa Ramadan. Polsek Cikande Gelar Razia Miras dan PSK"

6. Kata Depan

a. Surat kabar edisi tanggal 9 Februari 2020

1) Judul berita

“Jakarta 'Kelelep' Lagi Nih! Hujan Deras, Air Laut Pasang, Kali Meluap. Warga Ngungsi di Kontener"

2) Analisis

Kata di Kontener dalam kalimat tersebut termasuk Pemenggalan Kata dan merupakan kata tidak baku karena kata di Kontener seharusnya menjadi kata di Kontainer karena Kata Depan seperti $d i$, ke, dan dari ditulis terpisah dari kata yang mengikutinya yang disebut dengan Pemenggalan Kata dalam PUEBI. Jadi, Penulisan yang tepat dalam judul surat kabar tersebut menjadi “Jakarta 'Kelelep' Lagi Nih! Hujan Deras, Air Laut Pasang, Kali Meluap. Warga Ngungsi di Kontainer"

b. Surat kabar edisi tanggal 14 Februari 2020

1) Judul berita "Lempar Kursi di Konggres PAN Apa Amien Rais Ikut Terlempar?"

2) Analisis

Kata Di Konggres dalam kalimat tersebut termasuk Pemenggalan Kata dan merupakan kata tidak baku karena kata Di Konggres seharusnya menjadi kata Di Kongres karena Kata Depan seperti $d i$, ke, dan dari ditulis terpisah dari kata yang mengikutinya yang disebut dengan Pemenggalan Kata dalam PUEBI. Jadi, Penulisan yang tepat dalam judul surat kabar tersebut menjadi "Lempar Kursi di Kongres PAN Apa Amien Rais Ikut Terlempar?"

7. Singkatan dan Akronim

a. Surat kabar edisi tanggal 12 Februari 2020

1) Judul berita

"Ketua MPR: Masyarakat Menghendaki PPHN. Amandemen UUD 1945"

2) Analisis

Kata Amandemen UUD 1945 dalam kalimat tersebut termasuk Singkatan dan Akronim dan merupakan kata tidak baku karena kata Amandemen 1945 seharusnya menjadi kata Amendemen 1945 karena singkatan yang terdiri dari huruf awal setiap kata nama lembaga pemerintah dan ketatanegaraan, lembaga pendidikan, badan atau organisasi serta nama dokumen resmi ditulis dengan huruf capital tanpa tanda titik yang disebut dengan Singkatan dan Akronim dalam PUEBI. Jadi, Penulisan yang tepat dalam judul surat kabar tersebut menjadi "Ketua MPR: Masyarakat Menghendaki PPHN. Amendemen UUD 1945"

b. Surat kabar edisi tanggal 1 Maret 2020

1) Judul berita "Melerai Remaja Tawuran Kaki Bripda Agus Disabet Sajam"

2) Analisis 
Kata Bripda Agus Disabet dalam kalimat tersebut termasuk Singkatan dan Akronim dan merupakan kata tidak baku karena kata Bripda Agus Disabet Sajam seharusnya menjadi kata Bripda. Agus Tersabet karena singkatan nama orang, gelar, jabatan, atau pangkat diikuti dengan tanda titik pada setiap unsur singkatan itu yang disebut dengan Singkatan dan Akronim dalam PUEBI. Jadi, Penulisan yang tepat dalam judul surat kabar tersebut menjadi "Melerai Remaja Tawuran Kaki Bripda Agus Tersabet Sajam"

8. Angka dan Bilangan

a. Surat kabar edisi tanggal 21 Februari 2020

1) Judul berita

"Minimarket Diacak-acak Maling. Gasak Belasan Slop Rokok dan CD"

2) Analisis

Kata Belasan Slop dalam kalimat tersebut termasuk Angka dan Bilangan dan merupakan kata tidak baku karena kata Belasan Slop seharusnya menjadi kata Belasan Slof karena bilangan dalam teks yang dapat dinyatakan dengan satu atau dua kata ditulis dengan huruf, kecuali jika dipakai secara berurutan seperti dalam perincian yang disebut dengan Angka dan Bilangan dalam PUEBI. Jadi, Penulisan yang tepat dalam judul surat kabar tersebut menjadi "Minimarket Diacak-acak Maling. Gasak Belasan Slof Rokok dan CD"

Tabel 2 Rekapitulasi Jenis Kesalahan Penulisan Kata Tidak Baku dalam Judul Berita Surat Kabar Pos Kota

\begin{tabular}{|c|c|c|}
\hline No. & Penulisan kata & Jumlah \\
\hline 1. & Kata Dasar & 5 Kata \\
\hline 2. & Kata Berimbuhan & 5 Kata \\
\hline 3. & Bentuk Ulang & 2 Kata \\
\hline 5. & Pemenggalan Kata & 3 Kata \\
\hline 6. & Kata Depan & 2 Kata \\
\hline 9. & Angka dan Bilangan & 1 Kata \\
\hline 10. & Kata Ganti & 0 Kata \\
\hline 11. & Kata Sandang & 0 Kata \\
\hline & Total & 25 Kata \\
\hline
\end{tabular}

Pada tabel di atas peneliti sudah menghitung dari total 25 kata yang terbagi, Kata Dasar, Kata Berimbuhan, dan Gabungan Kata mendapatkan jumlah yang sama yaitu sebesar 5 kata. Pemenggalan Kata mendapatkan 3 kata. Bentuk Ulang, Kata Depan, dan Singkatan dan Akronim mendapatkan 2 kata. Angka dan Bilangan mendapatkan 1 kata, sedangkan, Partikel, Kata Ganti serta Kata Sandang tidak ditemukan datanya.

\section{Simpulan}

Setelah menghitung dan memilah judul surat kabar Pos Kota peneliti mendapatkan total 25 kata yang terbagi, Kata Dasar, Kata Berimbuhan, dan Gabungan Kata mendapatkan jumlah yang sama yaitu sebesar 5 kata. Pemenggalan Kata mendapatkan 3 kata. Bentuk Ulang, Kata Depan, dan Singkatan dan Akronim mendapatkan 2 kata. Angka dan Bilangan mendapatkan 1 kata, sedangkan, Partikel, Kata Ganti serta Kata Sandang tidak ditemukan datanya. Dari hasil penelitian ini dapat disimpulkan bahwa masih 
terdapat penggunaan kosakata yang tidak baku di dalam penulisan judul berita pada surat kabar Pos Kota edisi Februari sampai dengan Maret 2020. Penggunaan kosakata yang tidak baku pada judul berita surat kabar Pos Kota tersebut perlu dihindari pada terbitan edisi selanjutnya.

\section{Ucapan Terima Kasih}

Penulis mengucapkan banyak terima kasih kepada pihak-pihak yang telah membantu proses berjalannya penelitian ini dari awal hingga akhir dan sampai menjadi tersusunnya artikel ini. Ucapan terima kasih penulis sampaikan kepada Pimpinan Redaksi Jurnal Hortatori yang telah menerbitkan artikel hasil penelitian tentang penulisan kata tidak baku pada judul berita Pos Kota ini, Ketua Program Studi Pendidikan Bahasa Indonesia Universitas Indraprasta PGRI yang telah memberikan dukungan, semangat, dan doanya kepada penulis, dan para dosen pembimbing yang telah membantu memberikan data penelitian yang dibutuhkan oleh penulis. Semoga tulisan ini bermanfaat bagi banyak orang.

\section{Daftar Rujukan}

Abdulkarim, Aim, Asmawi Zainul, and Enok Maryani. "Perilaku asertif dan kecenderungan kenakalan remaja berdasarkan pola asuh dan peran media massa." Jurnal Psikologi 41.1 (2014): 74-88. https://doi.org/10.22146/jpsi.6959

Amalia, Suci Nur. "Pengembangan Bahan Ajar Menulis Berita Peristiwa Multikultural dengan Pendekatan Kontekstual." Jurnal Pendidikan Bahasa dan Sastra Indonesia 5.1 (2016). http://lib.unnes.ac.id/id/eprint/19836

Anto, Puji, M. Sjafei Andrijanto, and Taufiq Akbar. "Perancangan buku pedoman umum ejaan bahasa Indonesia sebagai media pembelajaran di sekolah." Jurnal Desain 4.02 (2017): 92-99. http://dx.doi.org/10.30998/jurnaldesain.v4i02.1131

Dewi, Mariani. "Gaya Bahasa Berita Media Online di Indonesia: Judul Menarik Tidak Harus Tidak Baku." Humaniora 5.2 (2014): 1015-1022. https://doi.org/10.21512/humaniora.v5i2.3212

Fakhrudin, Mohammad, Khabib Sholeh, and Umi Faizah. "Kata Baku pada Karya Ilmiah Mahasiswa Program Studi Pendidikan Bahasa dan Sastra Indonesia Universitas Muhammadiyah Purworejo." Jurnal Bahtera-Jurnal Pendidikan Bahasa Sastra dan Budaya 6.11 (2019). https://doi.org/10.37729/btr.v6i11.5548

Jamilah, Jamilah. "Penggunaan bahasa baku dalam karya ilmiah mahasiswa." Tarbiyah: Jurnal Ilmiah Kependidikan 6.2 (2017). http://dx.doi.org/10.18592/tarbiyah.v6i2.1603

Nuryastini, Yulianti, Ajeng Rita Nurdian, and Wikanengsih Wikanengsih. "Kemampuan Penggunaan Bahasa Baku Mahasiswa Progrm Studi Bahasa Indonesia IKIP Siliwangi di Media Sosial Instagram." Parole (Jurnal Pendidikan Bahasa dan Sastra Indonesia) 1.4 (2018): 475480.http://dx.doi.org/10.22460/p.v1i4p475-480.821

Rahardja, Untung, Ninda Lutfiani, and Resti Rahmawati. "Persepsi Mahasiswa Terhadap Berita Pada Website APTISI." SISFOTENIKA 8.2 (2018): 117-127. http://dx.doi.org/10.30700/jst.v8i2.400

Respati, Wira. "Transformasi Media Massa Menuju Era Masyarakat Informasi di Indonesia." Humaniora 5.1 (2014): 39-51.

Rizky, Muhammad. "Analisis Framing Berita Penertiban Minimarket Ilegal pada Surat Kabar Pos Kota dan Indopos." Wacana: Jurnal Ilmiah Ilmu Komunikasi 11.2 (2017): 122-131. https://doi.org/10.32509/wacana.v11i2.176

Rosana, Anita Septiani. "Kesenjangan Akses Informasi di Era Globalisasi (Sebuah Kajian Etika Media)." Jurnal Ilmiah Komunikasi Makna 4.1 (2013): 71-79. http://dx.doi.org/10.30659/jikm.4.1.71-79

Setiawati, Sulis. "Penggunaan Kamus Besar Bahasa Indonesia (KBBI) dalam Pembelajaran Kosakata Baku dan Tidak Baku pada Siswa Kelas IV SD." Jurnal Gramatika 2.1 (2016): 80391. https://doi.org/10.22202/jg.2016.v2i1.1408

Susanto, Eko Harry. "Media Massa, Pemerintah dan Pemilik Modal." Jurnal Aspikom 1.6 (2017): 477484. http://dx.doi.org/10.24329/aspikom.v1i6.53

Taufik, Mohamad. "Infografis sebagai bahasa visual pada surat kabar Tempo." Techno. Com 11.4 (2012): 156-163. https://doi.org/10.33633/tc.v11i4.1010 